\title{
Study of Spatial Systems in the Form of Bajo Tribe House in Wuring Village of Maumere City
}

\author{
Ambrosius A.K.S. Gobang ${ }^{1}$, Antariksa ${ }^{2}$, Agung Murti Nugroho ${ }^{3}$ \\ ${ }^{1}$ Post Graduate Students of Architecture of Built Environment, UB Malang \\ ${ }^{2}$ Lecturer of Architecture of Built Environment, UB Malang \\ ${ }^{3}$ Lecturer of Architecture of Built Environment, UB Malang
}

\begin{abstract}
Abstrak
Kata kunci: sistem spasial, hunian, Suku Bajo, kampung Wuring.

Spasial hunian Suku Bajo di kampung Wuring Kota Maumere dilihat pada karakteristik hunian masyarakat sebagai kampung awal peradaban muslim dan menjadi pusat penyebaran agama Islam di Kabupaten Sikka. Latar belakang sejarah sebagai tinjauan dalam menggali terbentuknya hunian masyarakat serta aspek geografis, sosial, budaya dan ekonomi masyarakat setempat. Pendekatan dalam penelitian ini menggunakan metode fenomenologi dengan analisa deskriptif kualitatif dan bersifat naturalistik yaitu menggambarkan dan menginterpretasi catatan budaya Suku Bajo berupa keterangan sejarah, dokumen peta, maupun artefak yang berwujud fisik hunian masyarakat Suku Bajo. Tujuan penelitian ini untuk mengkaji spasial yang terbentuk berupa sistem spasial hunian dan aspek-aspek yang melandasi pembentukan spasial hunian Suku Bajo pada kawasan kampung Wuring sebagai upaya untuk memahami kondisi awal hingga terbentuknya hunian kampung saat ini. Hasil penelitian memberikan gambaran tentang sistem spasial hunian mencakup organisasi ruang, orientasi ruang dan hirarki ruang dalam lingkup mikro hunian berupa konsep ma'bunda-ma'buli yang berdampak terhadap messo lingkungan karena adanya aspek non fisik yang melandasi pembentukan spasial hunian di kawasan kampung Wuring.
\end{abstract}

Keywords: spatial system, dwelling, Bajo Tribe, Wuring village.

\section{Abstract}

Spatial occupancy of Bajo Tribe in Wuring Town of Maumere City is seen on the characteristics of residential society as the early village of Muslim civilization and became the center of Islamic spreading in Sikka Regency. Historical background is as a review in exploring the formation of community dwelling and geographical, social, cultural and economic aspects of the local community. Approach in this research is using phenomenology method with qualitative descriptive and naturalistic analysis that is describing and interpreting cultural record of Bajo Tribe in the form of description of history, map document, or artefact which in the form of physical resident of Bajo tribe society. The purpose of this study is to examine the spatial formed in the form of spatial systems of occupancy and the aspects underlying the spatial establishment of Bajo Tribe in Wuring kampung area as an effort to understand the initial condition until the formation of the present kampung hamlet. The results of the study provide an overview of the spatial system of occupancy including organization of space, space orientation and space hierarchy within the scope of microdwelling ma'bunda-ma'buli concept that affects the environment messo because of non-physical aspects underlying the spatial formation of dwelling in Wuring village area.

@ 2017 The Authors. Published by GKAK UNMER Malang

*Corresponding Author: aagobangg@gmail.com, antariksa@brawijaya.ac.id, sasimurti@yahoo.co.id 


\section{INTRODUCTION}

The existence of shelter in marine waters in coastal areas in Indonesia generally formed in groups. Residential groups are formed as a result of thinking to settle for maritime communities, especially in coastal areas on shipping routes and trade in Southeast Asia. Coastal areas are closely related to the existence of fishing communities that the fishermen live, grow and develop in coastal areas or transition areas between land and sea (Kusnadi, 2009).

Shelter on the coast is a physical dwelling located in the transition area between the land area and the ocean with the majority of people work as fishermen. This fisherman society is formed as a community with a culture that is influenced by the value system and symbol of maritime community to shape its dwelling. Nuance of togetherness places on the coast is a common place through the arrangement of the distance between each dwelling (Nugroho, 2015).

The process of the formation of Bajo Tribe residents in Wuring village is to date, not separated from the geographical conditions and natural environment and daily activities of citizens as fishermen or sailors. However, people in this region also want a positive development in the environment. Kampung Wuring was chosen as the locus in this study because it has become a community residence identical with the Bajo people who live on the sea and have enough impact on the regional development of Maumere City. Besides, there is no massive study about the existence of Bajo Tribe in this Wuring village. Its strategic location is as a port became a center of trade as well as a center of Islamic propagation. The traditional fishing village in Wuring has now been established by the Sikka District Government as a tourist destination for both domestic and international tourists.

\section{LITERATURE REVIEW}

Understanding of occupancy according to Law no. 1 Year 2011 on Housing and Settlements, had seen from the definition of a house is a building that serves as a residence or occupancy and means of fostering the family. The home is an integral part of the settlement, and not a physical result of a mere phenomenon, but a process that is constantly evolving and linked to the socio-economic mobility of its inhabitants. There is an interaction between the house and the occupants that is what the house gives to the occupants as well as what the residents do to the house (Turner, 1972). The occupancy terminology is used in this study because it contains the physical meaning of the house and the occupants that contribute to the spatial formation and its development.

Spatial arrangement is an organizational relationship to a physical environment consisting of various objects and people, formed through certain spaces or spaces (Antariksa, 2011). Spatial or spacer meaningful distance, space between fields or space between objects (Act No. 4 of 2011 on Geospatial Information). Spatial meanings are physical spaces built in residential areas, residential houses and building forms by the presence of several factors that develop in the community (Mulyati in Prihanto, 2006). Spatial system is the fundamental and most stable aspect because it is formed according to the pattern of human behavior. Spatial systems related to space organization, space orientation and space hierarchy (Habraken in Ciptadi, 2014). Space arrangement or spatial setting of was an interaction between humans and their environment can be seen from several variables namely space, time, activity and perpetrator (Rapoport, 1990). The study of spatial order in question is the order of behavior in the physical space that becomes the place of activity and interaction between individuals and between individu- 


\section{Study Of Spatial Systems in The Form of Bajo Tribe House In Wuring Village of Maumere City}

Ambrosius A.K.S. Gobang, Antariksa, Agung Murti Nugroho

als and their environment. In relation to this research, spatial dwelling formed by Bajo Tribe society is a real event and need to be studied more about spatial physical that can be seen with approach of spatial system theory and also aspect that exist in socio-cultural life of society which can be seen with approach The theory of spatial settings.

\section{METHOD}

Spatial formation of the dwelling is studied by qualitative work, especially phenomenology. Emphasis on any form of scientific fact or event that can be seen scientifically (Moleong, 2002). Selection approach is based on the understanding that human and human aspects are very rich and related spatial architecture. The data collected include: physical data (space organization, space orientation, space hierarchy, spatial relations, zones, building layout) and non-physical data (social, religion, livelihood, knowledge, and lifestyle). The analysis is conducted qualitatively to the physical form that emerged from the socio-cultural process of the community to be seen the effect on the emergence of spatial system of dwelling. Spatial system analysis and spatial setting are performed on residential and environmental space scale.

\section{RESULTS AND DISCUSSION}

\section{Historical Review}

As for other historical stories that mention that the Bajo people from Permaan Island first entered Maumere through the territory of Tou, Kota Baru. The early Bajo tribe community in Tou numbered 17 heads of families, headed by a village chief known as Pijung Juma. Pijung Juma is a good relationship with King Sikka dubbed Moang Bako Kikir Hiwa (Ninth Finger). Kampung Wuring also entered the scope of development and government of Sikka Kingdom since the time of Don Thomas Ximenes da Silva (1922-1954). King Thomas allowed the people of the Bajo tribe to enter in Wuring village.

Wuring is chosen to be a residence because of its strategic location as a port and is identical with Bajo people who rely on seafood. The potential of Wuring as a bustling commercial airport makes this place as the entrance gateway and the assimilation of various cultures. Bugis tribes, Buton, Selayar, Java, Palue and Ende Island that entered after the Bajo tribe came to Wuring over for this economic reason. That is common in coastal communities, marital relations, Islamic religious broadcasting and other interactions helped shape the creation of the highly multicultural village of Wuring now.

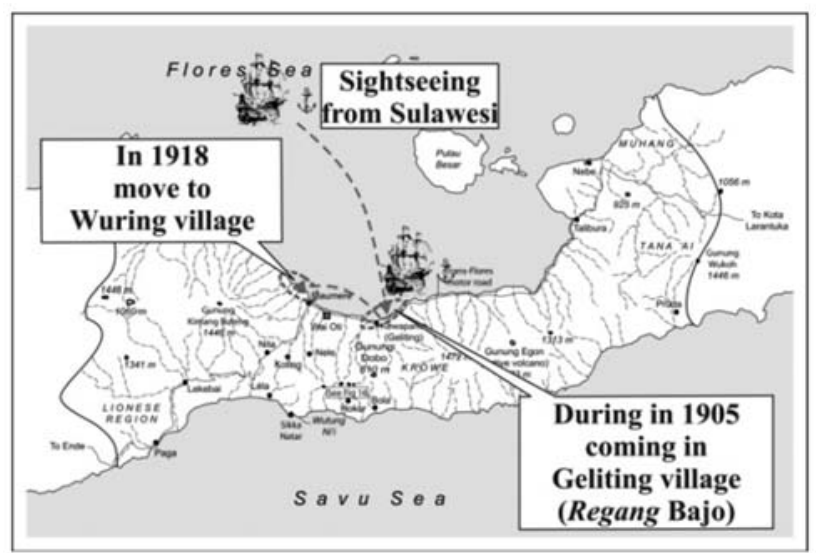

Figure 1. Map of the movement of the Bajo Tribe Source: Tourism Office Kab. Sikka, 2017

\section{Review of the Study Object}

Based on the spatial physical development of the village, Bajo tribe people divided into three parts namely Wuring Leko as the beginning of village formation, Central Wuring (tangah) and Tip Wuring (toroh). By the interview result, it is ex- 
plained that the development of Wuring village starts from leko or area around Maumere bay and tends to grow northward following taka pattern. The word taka in Bajo is coral or a cluster of corals in the sea and shallow. On top of this taka then Bajo tribe people do fish catching activities by parking a boat or boat house that over time the community planted the poles and built his dwelling and slowly accumulate the taka into the mainland. This tendency can explain the current situation of Wuring kampoeng that is Central Wuring and Tip (sea) Wuring which has become the mainland was originally waters with taka that stockpiled by Bajo Tribe people.



Figure 2. Pattern of taka in Maumere bay Source: Google Earth, 2017

Bajo tribes always choose a place to live not far from sea water, because almost all his life depends on the sea. Shelter with a simple stage shape decorated with a small boat or boat in front of it, so that the page looks like sea water. The division of the Bajo Tribal Zone on the Wuring coast follows the phases of physical development of the village from the efforts of the Bajo Tribe people by slowly accumulating taka starting from Wuring Leko growing north to Central Wuring and growing again north into Tip (sea) Wuring.



Figure 3. Map of Wuring village Source: Field Observation, 2017

\section{Spatial Settlement and Residential Review}

The data in the Wolomarang urban village office shows that Wuring village in 2017 is inhabited by 3018 people with 715 families and dominated by Bajo tribe people who live as fishermen. In Wuring village there are 662 houses located in Wuring Leko, Central Wuring and Wuring Laut and divided into two groups of shelters on land and on the sea that are affected by tides.

The layout of the Bajo houses in Wuring is built close together, as seen in the Middle Wuring section. The distance between one stage house with 


\section{Study Of Spatial Systems in The Form of Bajo Tribe House In Wuring Village of Maumere City}

Ambrosius A.K.S. Gobang, Antariksa, Agung Murti Nugroho

another stage house approximately 1.5-2 meters with an average height of about 2-4 meters. Getting to the middle of the sea, the stage house is getting higher because the plains are getting sloping, while the housing in Wuring Laut is still quite sparse and there are still empty spaces for new stage houses built. Currently Bajo tribal residence in Wuring village can be classified into two groups as follows:

a. Group occupancy on the ground or land of the heap.

All residences on the left and right of the main road and other neighborhood roads are occupancies on the ground. It has a roofed front porch and a backyard that is open space. House width averaging 5-7 meters with varying length. The distance between houses is generally 1.5-2.0 meters. The space beside the house is used as a road connecting environment and the space under the house is used to store goods or for recreational activities and other economic.

b. Group of marine settlements affected by ups and downs.

It has a roofed front porch or just a wide eyebrow. In the water chamber after the back porch there is an area to moor the boat. The width of the house an average of 5-7 meters with varying length. The distance between houses is generally 1.5-2.0 meters. One of the space beside the house used as a path to the house on the back. Occupancy in this group, especially in the middle generally do not have a back porch due to limited land where space behind the house has become a residential land for the house behind him. There is also a space for drying that is built together with the back and front porch and next to the house if there is still empty space. After the boat mooring area, sometimes there are karamba owned by residents who live on land. Water space beside the house is used as a boat road to the house in front of it.

Based on the results of interviews to 24 residents (residential cases) and validated by in-depth interviews to seven key person elders (occupancy case $04.05,09,13,15,17,22)$, it can be explained that the initial form of Bajo tribe in Wuring village Form a single stage, which by the local community called roma toloh. The Characteristic from early Bajo tribal architecture is a symmetrical and orthogonal structure of the plan (horizontal) and cut (vertical). In the Bajo Tribe architecture, bundaang-buliang and rumak-diaruma are considered the main spaces in the composition of residential buildings as a whole.

The contents of a house consists of several members of the nuclear family, and generally become a large family of in-laws, cousins, and others. At first Bajo people only know limited space, namely: a) tingnga (bedroom), b) bundaang (front room or living room), c) kitchen (kitchen), d) paselo (front porch), e) tatambe (back porch with pole), and e) buliang (back room). As the occupancy above the water, in addition to dry areas parallel to the road is also known diaruma which is an area under the dwelling.

The creation of the architecture of the house of Bajo is motivated by a cultural principle sama di lao malabu-madara. In this culture there are important values in the life of the Bajo tribe that is equally in the sea so that the formation of living space becomes a symbol of the existence of binders, controllers and respect vertically and horizontally. The values they contain are the basic concepts of the theory of settlement architecture based on local knowledge, among others mao ma di lao", dapu" ma in laok (sea belonging to the Bajo people), umbo ma di lao" (sea mother) and some marine space philosophy. 


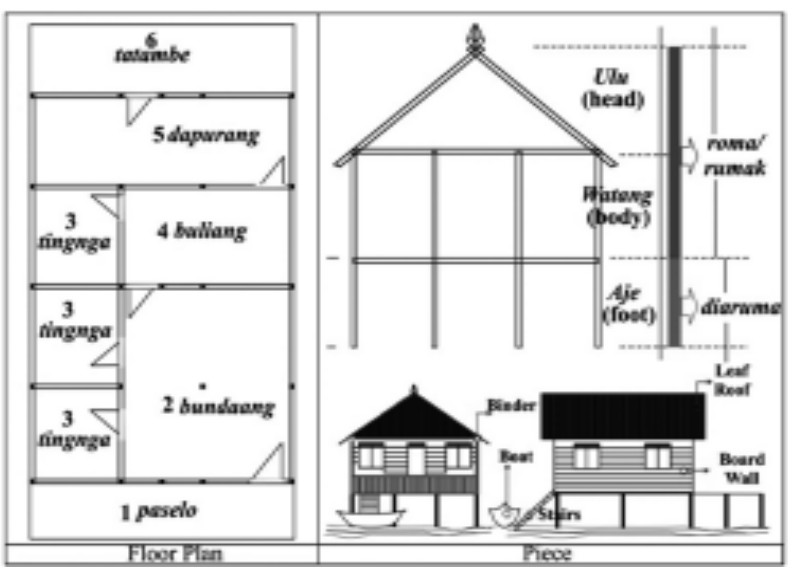

Figure 4. Early form of Bajo tribal residence Source: Key Person Interview Result, 2017

\section{Spatial System Formation}

a. Organization of Residential Spaces

The pattern of micro space organization (shelter or residence) of society affects the development of space messo and macro area of Wuring village, because the dwelling built especially on the sea is always accompanied by the motive of land tenure and in addition to that with the tatambe (back porch) and The new dwelling is also supported by the presence of a wide and jutting taka to the north, so taka also has the potential to be dumped and become the mainland.

Indications obtained that the organization of this micro space is formed linearly extending from front to back consisting of several main spaces namely paselo (front porch), bundaang (living room), tingnga (bedroom), buliang (family room), kitchen (kitchen), tatambe (back porch). The horizontal shape of the house plan can be explained that the composition of the building has an imaginary axis composed of micro spaces, ie, placing the main space in two parts and other spaces placed on the left or rear side of the overall arrangement. There are two major parts that organize the above mentioned spaces: the fronts represented by the bundaang and the back are represented by buliang, so by the more popular Bajo tribe people are called ma'bunda and ma'buli.

If there is spatial development of the dwelling, the organization of residential space will become more complex and massive because in one dwelling there are two organizations of space in one dwelling.

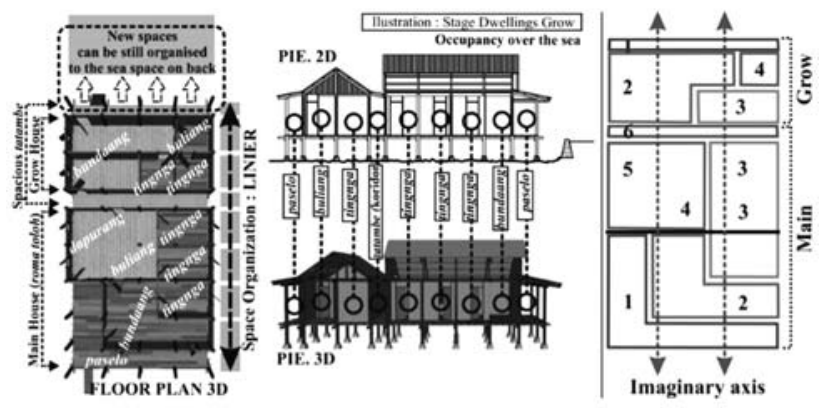

Figure 5. Organization space and axis shelter plan Source: Analysis Result, 2017

\section{b. Residential Room Orientation}

The philosophy sama di lao is still preserved in the form of dwelling, where the most ideal settlement according to the same in lao is facing to a space that is the sea at the back and circulation paths in front or next to the house, so that residents can more easily interact and action in space Sea and space in front of him. In addition, the orientation of space is in the space bundaang and buliang. The spatial orientation review is viewed in a review of environmental messaging and micro occupancy. Spatial orientation shows in a space, on the circulation path and on an imaginary axis. Differences in space orientation are also seen in occupancy on land and over the sea. If the land occupancy is oriented to an imaginary axis in the form of the composition of the houses in front of it or the circulation network in the form of the road that lies ahead, the house above the sea is unique especially in the developed house, for example in the case of 09 


\section{Study Of Spatial Systems in The Form of Bajo Tribe House In Wuring Village of Maumere City}

Ambrosius A.K.S. Gobang, Antariksa, Agung Murti Nugroho

house looks oriented house on the circulation network and the composition of the houses in front of it while the home grows oriented to a space of space sea. So the house that grows in the back is made as a terrace for access to the sea for the main house in front of it.

Residential space orientation can have an effect on spatial system of occupancy. For example, the orientation on the imaginary axis is the location of the residential lined with other dwellings on the side and behind causing the house a bit difficult to develop because there is no more space at the side or behind. In contrast to the orientation of shelter in a space that is the space of the sea will be more flexible in the formation of spatial system, for example in the form of shelter stage that grows located above the sea.

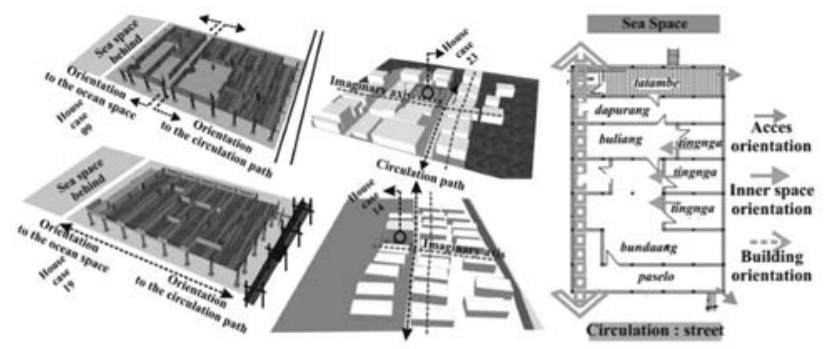

Figure 6. Orientation of environmental messo space and axis of shelter plan Source: Analysis Result, 2017

Orientation of space in the occupancy can be explained that there is a certain space, especially bedrooms (tingnga) arranged in a linear or oriented to a space that is behind the bedroom is always parallel to the bedroom in front of him and face to face in space bundaang and buliang in front of it. This is similar to the arrangement of houses in the outer space orientation.

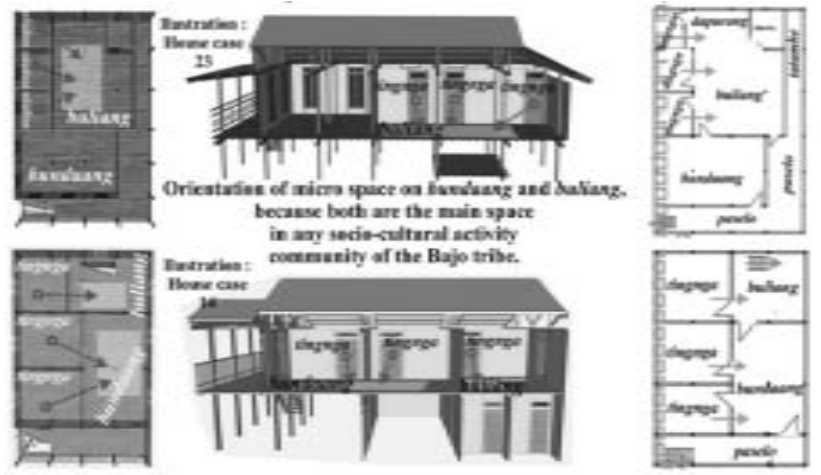

Figure 7. Orientation of micro space and axis of shelter plan Source: Analysis Result, 2017

c. Residential Room Hierarchy

The hierarchical pattern of space formed in the dwelling consists of two main spaces, namely bundaang and buliang Bajo Tribe house generally. The bundaang or living room only represents the two front rooms (ma'bunda-ang) is paselo (front porch) and bundaang (living room) where as buliang or family room representing the back rooms (ma'buli-ang) includes two tingnga (bedroom) the back, buliang (living room), dapurang (kitchen) and tatambe (back porch). Under certain conditions such as inhome celebrations, this division of space represents a hierarchical phenomenon or level of space within the house, as there will be $m a^{\prime} b u n d a$ for men and ma'buli for women. The division of this space is also confirmed by the massive dividing wall with door access in the middle. Hierarchically, the spaces in Bajo tribe residence are divided into 2 (two) major parts namely bundaang (front room) and buliang (back room). Bundaang and buliang are two parts of space that must exist in the homes of the Bajo tribe because they provide the meaning of hierarchy of space in the dwelling at every ceremony or custom ritual performed 
in the house. There is also a residential house that no longer has a clear boundary between the front room (bundaang) and the back room (buliang) due to socio-cultural development and economic level that lies behind it.

The phenomenon of ma'bunda-ma'buli places bundaang and buliang as two big parts of spatial arrangement in Bajo tribe, because each parts organises some spaces that ma'bundaang which is semi public consists of living room, terrace and bed room front while semi-private ma'buliang consists of living room, back bedroom, kitchen and back porch.

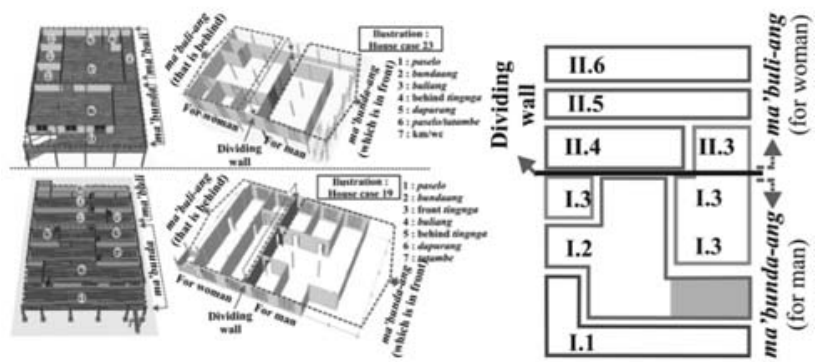

Figure 8. Hierarchy of space and axis of shelter plan Source: Analysis Result, 2017

But in the daily life of the Bajo Tribe people, mentioning bundaang more associated to the living room and buliang associated to the family room. Ma'bunda phenomenon (for men) and ma'buli (for women) is also a manifestation of the pattern of division of prayer places in the mosque space that there is a separation between men and women. Bundaang and buliang is the main room of every Bajo house.

The spatial development of the dwelling also gives a significant impact in the composition of residential micro space and hierarchy of residential space. The impact of space hierarchy that occurs in occupancy with massive spatial development is more to the location of micro spaces that tend to be irregular eg kitchen and buliang that have been fused and the double function of paselo space that can be tatambe.

\section{Environmental Hue (Setting) Activity}

Non-physical aspects underlying the formation of environmental tiles and spatial arrangements (settlement spatial) Bajo tribal settlements include:

a. On the aspect of space shows that there is inter-linkage between space activities in the micro scale of the house or community dwelling and messo public facilities such as a place of fish drying, fish ports, fish auctions and markets.

b. There is a time division of community activity that is at 11:00 to 14:00 pm only visible women and children in the village of Wuring just gather and mingle or drying fish around the

Table 1. The hierarchical arrangement of Bajo tribal living spaces in Wuring village

\begin{tabular}{|c|c|c|c|c|c|c|c|c|}
\hline \multirow[b]{2}{*}{ No } & \multirow[b]{2}{*}{ Space name } & \multicolumn{4}{|c|}{ Hierarchy space } & \multicolumn{3}{|c|}{ Space part } \\
\hline & & Privat & $\begin{array}{l}\text { Semi } \\
\text { Privat }\end{array}$ & General & Semi Publik & Service & $\begin{array}{l}\text { Front part } \\
\text { (ma'bunda) }\end{array}$ & $\begin{array}{l}\text { Backpart } \\
\text { (ma'buli) }\end{array}$ \\
\hline 1 & Paselo & & & $\checkmark$ & & & $\checkmark$ & \\
\hline 2 & Bundaang & & & & $\checkmark$ & & $\checkmark$ & \\
\hline 3 & Front Tingnga & $\checkmark$ & & & & & $\checkmark$ & \\
\hline 4 & Buliang & & $\checkmark$ & & & & & $\checkmark$ \\
\hline 5 & Behind Tingnga & $\checkmark$ & & & & & & $\checkmark$ \\
\hline 6 & Dapurang & & $\checkmark$ & & & & & $\checkmark$ \\
\hline 7 & Tatambe & & & & $\checkmark$ & & & $\checkmark$ \\
\hline 8 & Bathroom/Toilet & & & & & $\checkmark$ & & $\checkmark$ \\
\hline
\end{tabular}

Source: Analysis Result, 2017 


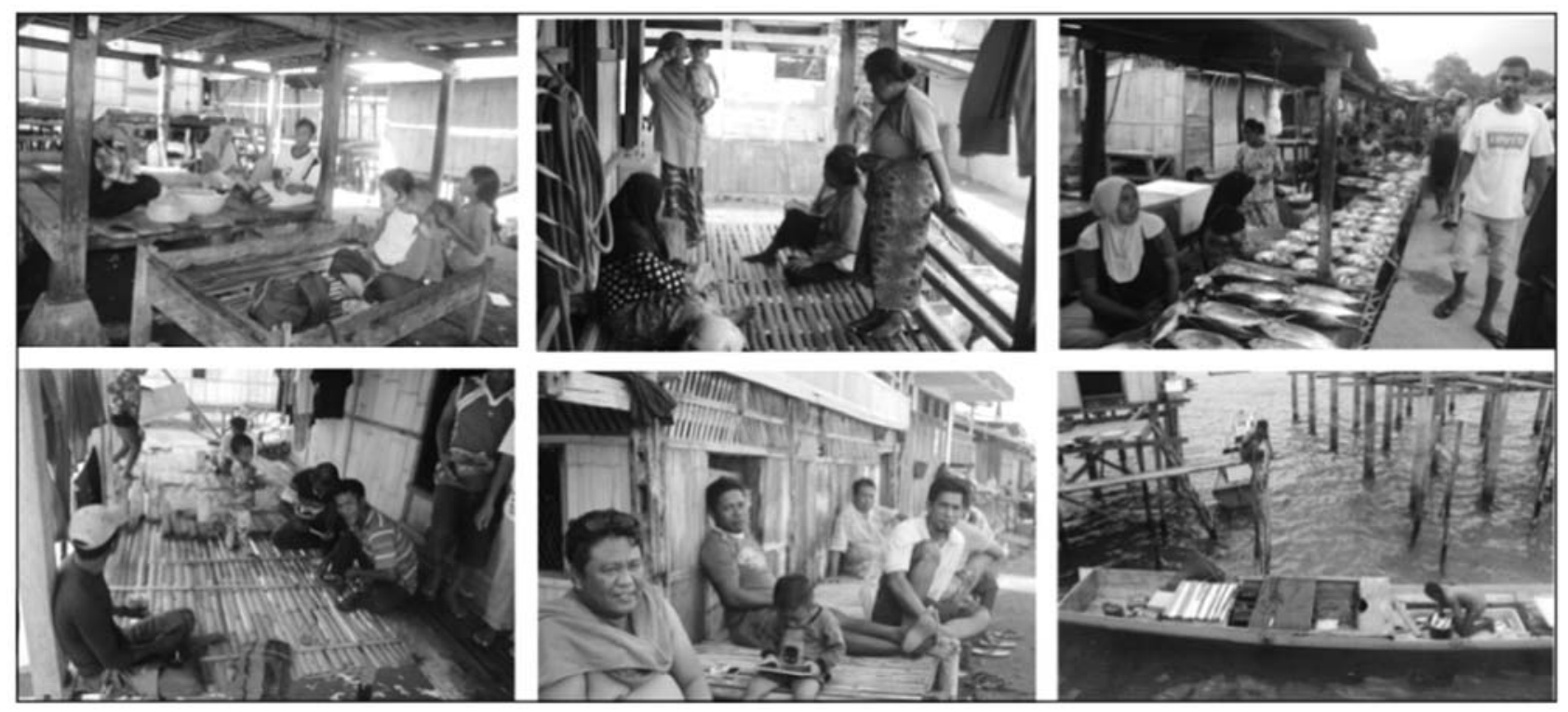

Figure 9. Community Activities of Bajo Tribe in residential area Source: Field Observation, 2017

neighborhood or residential space like in the yard, diaruma, paselo and tatambe while waiting for the husbands back From the sea. In the messo room at 15:00 to 19:00 wita Wuring village began to look crowded with a variety of activities, especially women who prepare merchandise such as snacks and catches of men to sell in the market.

c. Activities undertaken such as deliberation of fishermen and his group before going to sea or just gather together is usually done in the room diaruma or paselo. In addition there is also a ritual macca (read prayer), where men will occupy the bundaang (front room) and the women will occupy buliang (back room).

d. Activity actors are Bajo Tribe people from groups of men and women where there is a specification of the type of activity.

e. There are other socio-cultural factors that underlie the formation of occupancy, among others, because internal factors include the level of education, income, increase or decrease the number of family members and external factors include the natural environment, other cultural influences and government intervention.

\section{CONCLUSION}

Based on the results and discussion can be concluded that the spatial system that is formed in the Bajo Tribe on the coast of Wuring Maumere City found the concept of ma'bunda-ma'buli where the form of space organization becomes complex in the dwelling that has grown both on land and at sea. The form of orientation of shelter in a messo environment looks more dominant building oriented to a space that is sea and circulation path while in space or in micro occupancy seen orientation of space in two main room that is bundaang and buliang. The hierarchical form of space is also divided into two major parts that refer to the two main chambers where each space bundaang and buliang represent some space in the dwelling. The spatial system that develops in the formation of 
residential microstructure has an impact on the environment messo space based on several aspects of the spatial setting (hue environment) and the non-physical or socio-cultural aspects of the Bajo tribe such as kinship or kinship (increasing the number of family members), activity type and activity actors, level of community education (understanding and appreciation of the values of settled traditions), economic level (housing development financing), cultural assimilation process and government intervention.

\section{REFERENCE}

[1] Antariksa. (2011, February 18). The influence of culture and customs of society in traditional settlements. Accessed October 12, 2016, from antariksaarticle.blogspot.com.

[2] Ciptadi, Wahyudin. (2014). Organizational Pattern Change, Hierarchy And Orientation Of Traditional Malay Living Room Pontianak Type Cut Limas Around Kraton Kadriyah Pontianak Complex. Journal of Vocational, X (2), 89-97.

[2] Habraken, N. J. (1978). General Principles A Bout the Way Built Environment Exist. Massachusetts: MIT Press.

[3] Kusnadi. 2009. The existence of Fishermen and Coastal Economy Dynamics. Yogyakarta: ArRuzzMedia.
[4] Moleong, Lexy J. 2002. Qualitative Research Methods. Bandung: PT Remaja Rosdakarya.

[5] Mulyati, A. (1995). Spatial Pattern of Settlements in Kauman Village Yogyakarta. Yogyakarta: Rake Sarasin.

[6] Nugroho, Agung Murti. (2015). Sustainability of the archipelago built in the coastal area. In Wuisang, Cynthia \& Kumurur, Veronica (Ed.), Proceedings of IPLBI Scientific Meeting: B039-B044. Manado: Sam Ratulangi University.

[7] Prihanto, Teguh. (2008). The influence of socio-cultural life on spatial settlement in Kelurahan Sekaran as a suburb of Semarang City. Journal of Civil Engineering and Planning, X (2), 93-102.

[7] Rapoport, Amos. (1982). Human Aspects of Urban Form, Towards A Man Environment Aproach to Urban Form and Design. USA: Oxford University Press.

[8] Rapoport, Amos. (1990). System of activities and system of settings,. Dalam Kent (Ed.). Domestic Architecture and The Use of Space. Cambridge: Cambridge University Press.

[9] Turner, John F. C. (1972). Freedom to build: dweller control of the housing process. New York: Macmillan.

[10] Zacot, Francois R. (2008). Bajo people, Sea nomads. On. Fida Muljono and Ida Budi Pranoto. Jakarta: Gramedia EFEO-FJP. 